\title{
KETERAMPILAN MENGOBSERVASI SISWA SEKOLAH DASAR DALAM PEMBELAJARAN IPS
}

\author{
Ode Sofyan Hardi ${ }^{1}$, Kiki Rumantir ${ }^{2}$ \\ 1 Dosen Geografi FIS UNJ, 2Mahasisiwa Geografi FIS UNJ \\ JI. Rawamangun Muka Gedung K Lantai 2 FIS UNJ Jakarta Timur 13220 Indonesia \\ ode-sofyan-hardi@unj.ac.id
}

\begin{abstract}
ABSTRAK
Tujuan penelitan ini adalah menggambarkan suatu feomena dalam pembelajaran tematik di Sekolah Dasar, yang dimana kemampuan observasi itu termasuk dalam aspek keterampilan geografis. Metode penelitian ini menggunakan metode deskriptif dengan pendekatan survey, dengan mengambil sampel sekolah di SD Negeri Rawamangun 12 pagi, dan yang diambil sampel kelas di kelas $\mathrm{V}$, teknik analisis data yang digunakan adalah teknik deskripsi. Siswa yang melakukan observasi dapat di lihat dari beberapa aktifitas di bawah ini: Menggunakan berbagai perasaan untuk mengenali suatu objek. Mencatat dengan detail fakta yang relevan dari objek dan segala sesuatu di sekitarnya. Mengidentifikasikan persamaan dan perbedaan. Menggunakan alat dan bahan untuk memahami objek dengan detail. Hasil penelitian ini pada dasarnya siswa yang bersekolah di Sekolah Dasar Negeri Rawamangun 12 telah mampu mengobservasi objek-objek sosial dalam materi IPS dengan menggunakan metode inkuiri terbimbing siswa mengalami peningkatan yang signifikan. Penggunaan model-model yang mengutamakan aspek berpikir tinggat tinggi pada siswa, mengakibatkan sisiwa mengalami hasil belajar yang baik.
\end{abstract}

Kata kunci : Ketrampilan, Observasi, IImu Pengetahuan Sosial

ABSTRAC

The purpose of this study is to describe phenomena in thematic learning in elementary schools, where the ability to observe is included in the aspect of geographical skills. This research method uses descriptive method with a survey approach, by taking a sample of the school in SDN Rawamangun 12 Pagi, and taking a sample $V$ class .The data analysis technique used is the description technique. Students who make observations can be seen from several activities below: Using various feelings to recognize an object; Record in detail the relevant facts of the object and everything around it; Identify similarities and differences; Using tools and materials to understand objects in detail. The results of this study basically students who study at SDN Rawamangun 12 Pagi have been able to observe social objects in social studies material using guided inquiry methods students experienced a significant increase. The use of models that prioritize aspects of high thinking in students, so that students experience good learning outcomes.

Keywords: Skills, Observations, Social Sciences

\section{PENDAHULUAN}

Pembelajaran adalah proses interaksi peserta didik dengan pendidik dan sumber belajar pada suatu lingkungan belajar. Pembelajaran merupakan bantuan yang diberikan pendidik agar dapat terjadi proses pemerolehan ilmu dan pengetahuan, penguasaan kemahiran dan tabiat, serta pembentukan sikap dan kepercayaan pada peserta didik. Dengan kata lain, pembelajaran adalah proses untuk membantu peserta didik agar dapat belajar dengan baik. Proses pembelajaran dialami sepanjang hayat seorang manusia serta dapat berlaku di manapun dan kapanpun. Pembelajaran mempunyai pengertian yang mirip dengan pengajaran, walaupun mempunyai konotasi yang berbeda. Pembelajaran adalah pemberdayaan potensi peserta didik menjadi kompetensi. Kegiatan pemberdayaan ini tidak dapat berhasil tanpa ada orang yang membantu. Menurut Dimyati dan Mudjiono (Syaiful Sagala, 2011: 62) pembelajaran adalah kegiatan guru secara terprogram dalam desain instruksional, untuk membuat belajar secara aktif, yang menekankan pada penyediaan sumber belajar. 
Dalam Undang-Undang No. 20 Tahun 2003 Tentang Sistem Pendidikan Nasional pasal 1 ayat 20 dinyatakan bahwa Pembelajaran adalah proses interaksi peserta didik dengan pendidik dan sumber belajar pada suatu lingkungan belajar. Konsep pembelajaran menurut Corey (Syaiful Sagala, 2011: 61) adalah suatu proses dimana lingkungan seseorang secara disengaja dikelola untuk memungkinkan turut serta dalam tingkah laku tertentu dalam kondisi-kondisi khusus atau menghasilkan respons terhadap situasi tertentu, pembelajaran merupakan subset khusus dari pendidikan. Pembelajaran mengandung arti setiap kegiatan yang dirancang untuk membantu seseorang mempelajari suatu kemampuan dan nilai yang baru. Proses pembelajaran pada awalnya meminta guru untuk mengetahui kemampuan dasar yang dimiliki oleh siswa meliputi kemampuan dasarnya, motivasinya, latar belakang akademisnya, latar belakang ekonominya, dan lain sebagainya. Kesiapan guru untuk mengenal karakteristik siswa dalam pembelajaran merupakan modal utama penyampaian bahan belajar dan menjadi indikator suksesnya pelaksanaan pembelajaran. Dapat ditarik kesimpulan bahwa pembelajaran adalah usaha sadar dari guru untuk membuat siswa belajar, yaitu terjadinya perubahan tingkah laku pada diri siswa yang belajar, dimana perubahan itu dengan didapatkannya kemampuan baru yang berlaku dalam waktu yang relatif lama dan karena adanya usaha.

Winataputra (1996:78) menyatakan bahwa model pembelajaran merupakan kerangka konseptual yang melukiskan prosedur yang sistematis dalam mengorganisasikan pengalaman belajar untuk mencapai tujuan belajar tertentu dan berfungsi sebagai pedoman bagi para perancang pembelajaran dan para pengajar dalam merencanakan dan melaksanakan aktifitas belajar mengajar. Didalam perkembangannya tidak dapat dipungkiri bahwa manusia selalu berusaha mencapai efisiensi-efisiensi kerja dengan jalan memilih dan menggunakan suatu cara atau taktik yang dianggap terbaik untuk mencapai tujuan yang diharapkan. Demikian pula dengan kegiatan pembelajaran yang tepat dan dipandang lebih efektif sehingga tujuan pembelajaran dapat tercapai dengan baik.

Berdasarkan faktor-faktor di atas diharapkan guru dapat memilih model pembelajaran yang tepat untuk mencapai tujuan pembelajaran. Suatu model pembelajaran dikatakan baik jika penggunaannya tepat, memberikan hasil belajar yang optimal, serta dapat meningkatkan aktivitas belajar siswa.

Menurut Wheatley (Dalam Bektiarso, 1997:194), pembelajaran konstruktivisme mengandung dua prinsip yaitu pertama, pengetahuan tidak dapat diperoleh secara pasif tetapi secara aktif oleh struktur kognitif siswa. Kedua, fungsi kognisi bersifat adaptif dan membantu pengorganisasian melalui pengalaman nyata, sehingga siswa dapat mengumpulkan pertanyaan untuk memperoleh pengetahuan. Untuk menciptakan kelompok kerja yang efektif, pengajar atau guru perlu menyusun tugas sedemikian rupa, sehingga setiap anggota kelompok harus menyelesaikan tugasnya sendiri agar yang lain bisa mencapai tujuan mereka dan kunci keberhasilan kerja kelompok adalah persiapan guru dalam penyusunan tugasnya (Lie, 2002:31).

Menurut Joe Navarro, penulis buku "Spycatcher", tinggal di kota besar dengan jumlah penduduk yang banyak dapat menurunkan tingkat sensitivitas seseorang. Terlalu banyak bertemu dengan orang dengan tingkat proksimitas atau kedekatan yang cukup intim membuat siswa kekurangan waktu dan kelelahan untuk dapat mengobservasi orang dengan baik. Maka tak heran jika kemampuan observasi siswa semakin lama akan menjadi semakin tumpul sehingga sulit untuk menemukan temuan saat melakukan observasi. Berikut adalah delapan cara yang dapat siswa lakukan untuk meningkatkan kemampuan observasi, yaitu:

\section{Latih kemampuan bertanya siswa}

Bertanya adalah salah satu modal dasar seseorang untuk memperoleh informasi. Rasa ingin tahu menjadi kunci utama dalam poin ini. Dengan memiliki rasa ingin tahu yang tinggi, maka akan timbul dalam diri siswa hasrat untuk selalu penasaran sehingga secara otomatis siswa akan lebih banyak mencurahkan perhatian ke 
segala hal yang dapat menjawab rasa penasaran tersebut. Pertanyaan yang baik dalam observasi adalah pertanyaan yang dapat memancing subjek untuk bercerita tanpa membuatnya merasa tertekan atau merasa diawasi.

\section{Terapkan pemikiran yang terbuka}

Memiliki pemikiran yang terbuka dan reseptif sangat diperlukan dalam melakukan observasi. Sebagai manusia, pasti siswa memiliki personal bias, kepercayaan, dan level toleransi tertentu terhadap suatu informasi yang siswa terima. Saat melakukan observasi, siswa dituntut untuk objektif dan membuang semua bias tersebut. Objektivitas ini baru akan muncul jika siswa memiliki pemikiran yang terbuka.

\section{Tingkatkan kemampuan mengingat}

Observasi berbeda dengan melihat-lihat. Melakukan observasi berarti siswa melihat sekeliling dan menyimpannya dalam memori, agar dapat mengartikannya atau membuat pertanyaan terkait dari hasil temuan di lapangan. Untuk itu, biasakan untuk mengingat segala hal dengan lebih detail. Siswa bisa melatih memori siswa dengan bermain games mengingat benda di ponsel atau sekedar me-recall percakapan yang terjadi hari ini di malam hari sebelum tidur.

\section{Buat catatan lapangan}

Masih berkaitan dengan kebutuhan untuk mengingat, dalam observasi siswa diperbolehkan untuk membuat catatan lapangan selama hal tersebut tidak mengganggu jalannya observasi. Catatan lapangan bisa berupa tulisan singkat atau foto dalam jumlah yang sebanyak mungkin. Catatan ini akan memudahkan siswa untuk mengingat kembali hasil temuan dalam observasi. Siswa bisa mulai mencobanya dengan mengamati sekeliling ketika berjalan-jalan ke taman dan catat setiap detail yang siswa lihat. Lakukan hal ini secara berkala dan cobalah untuk menarik sebuah kesimpulan dari catatan yang telah siswa buat tersebut.

\section{Jangan mudah mengeneralisir keadaan}

Dalam melakukan observasi, siswa tidak boleh terburu-buru menarik kesimpulan. Hal ini dilakukan agar siswa tidak melewatkan temuan-temuan penting yang berharga bagi hasil observasi. Cobalah untuk menaruh perhatian lebih terhadap sesuatu hal agar siswa mendapatkan gambaran detailnya. Lakukan hal ini secara terus menerus hingga siswa dapat menemukan hal lain dari sesuatu yang selama ini siswa nilai sebagai hal yang biasa. Contohnya siswa bisa perhatikan keseharian rekan kerja siswa hingga siswa bisa menemukan hal unik dari kebiasaannya tersebut.

\section{Bersemangat}

Bersemangat sangat dibutuhkan dalam melakukan observasi. Ketika siswa bersemangat, ide-ide baru akan muncul dan siswa akan lebih bersungguh-sungguh dalam melakukan observasi. Jika hal ini terjadi, pasti akan lebih banyak lagi temuan yang akan siswa dapatkan di lapangan. Semakin banyak temuan tentu akan semakin mempermudah siswa untuk membuat kesimpulan, bukan? Untuk menumbuhkan rasa semangat, siswa bisa memulai dengan melakukan observasi pada hal-hal yang sesuai dengan minat siswa.

\section{Latihan observasi}

Agar kemampuan observasi semakin baik, siswa bisa melakukan beberapa kali latihan observasi untuk mempersiapkan diri melakukan observasi yang sesungguhnya. Latihan terdiri dari mendiskusikan dan mengingat kategori dalam observasi, coba membaca catatan lapangan yang telah dibuat, dan melakukan observasi lapangan dengan ditemani oleh pendamping. 


\section{Meditasi}

Meditasi dilakukan untuk menjernihkan pikiran dan menghilangkan distraksi agar siswa dapat fokus ketika melakukan observasi. Fokus dibutuhkan untuk mempermudah siswa melihat temuan penting di lapangan sehingga siswa dapat menghemat waktu dan tenaga dalam melakukan observasi. Siswa bisa melakukan meditasi atau relaksasi selama 10 sampai 15 menit per hari di tempat tenang atau sekadar mendengarkan musik-musik instrumental untuk meningkatkan fokus siswa.

Kualitas suatu observasi memang sangat bergantung pada kualitas observer itu sendiri. Delapan cara di atas bisa siswa terapkan agar kemampuan siswa untuk melihat "benang merah" dari hasil observasi dapat meningkat. Selamat mencoba!

Pertanyaan penelitian ini adalah bagaimana keterampilan mengobeservasi pada siswa untuk mata pelajaran tematik IPS di SD?

\section{METODE}

Metode penelian ini menggunakan metode deskriptif dengan pendekatan survey, dengan mengambil sampel sekolah di SD Negeri Rawamangun 12 pagi, dan yang diambil sampel kelas di kelas V, teknik analisis data yang digunakan adalah teknik deskripsi

\section{HASIL DAN PEMBAHASAN}

Menurut Jo-Ellan Dmitrius, P.hd. "Untuk mempertajam kemampuan observasi, ketika bertemu orang dengan orang yang baru ditemui, bayangkan kita mengambil snapshot dari orang tersebut. Bekukan imej orang tersebut di pikiran kita. Kemudian secara mental, mundur perlahan dan amati imej orang tersebut dari atas ke bawah. Kalian akan men-scan karakteristik fisik orang tersebut dan menyadari ciri-ciri yang konsisten dari orang tersebut, juga satu dua ciri yang kelihatan mencolok."

Menurut Harry Lorrayne, berikut adalah metode-metode untuk melatih kemampuan observasi:

a. Mempelajari sistem memori yang Harry Lorrayne susun. Bukunya How to Develop a Super Power Memory bisa di download melalui google.

b. Di ruangan yang familiar, ambil selembar kertas. Tanpa melihat sekeliling, jelaskan ruangan tersebut secara detail. Tulis satu persatu benda yang ada di ruangan tersebut Catat setiap aspek, furnitur, foto dan berbagai benda lainnya. Kemudian lihat ruangan tersebut. Cek benda-benda di daftar. Sadari ada beberapa benda yang terlewat atau bahkan tidak teramati sama sekali padahal sudah melihatnya beberapa kali. Kemudian keluar dari ruangan tersebut. Tes sekali lagi seperti sebelumnya. Kali ini, daftarnya pasti jauh lebih panjang dari sebelumnya. Cobalah hal ini pada ruangan lain di rumah. Jika hal ini dilakukan terus (dilatih), maka kemampuan observasi akan meningkat drastis.

c. Pikirkan seseorang yang kita kenal dengan baik. Cobalah untuk membayangkan wajahnya. Kemudian, coba deskripsikan wajahnya pada selembar kertas. Tulis apapun yang bis diingat. Kemudian, cobalah untuk lebih terperinci mendeskripsikan orang tersebut. Misal: warna rambut, gaya rambut, kulit, semua karakteristik yang mencolok, pakai kacamata atau tidak, tipe kacamatanya, tipe hidung, telinga, mata, dahi, perkiraan tinggi dan berat badan, dll. Ketika bertemu orang tersebut, cek tingkat kebenaran yang didapat. Catat mana yang benar dan mana yang salah. Kemudian, coba lagi latihan ini. Kemampuan akan meningkat drastis.

Cara terbaik untuk melakukan latihan ini adalah saat menaiki transportasi umum. Lihatlah orang yang berada di depan atau di samping . Lalu secara mental, deskripsikan secara detail karakteristik wajah orang tersebut. Pura-puralah seolah sebagai saksi dari perbuatan kriminal dan detail yang diamati sangatlah penting. Cek kembali, Setiap kali kebiasaan ini dilatih, keampuan observasi akan meningkat tajam. 
Berdasarkan situs wikihow, ada beberapa cara yang bisa dipakai untuk meningkatkan kemampuan observasi. Cara-cara tersebut adalah:

a. Mengambil kelas melukis dan menggambar

b. Luangkan waktu untuk mengamati orang dari jauh. Situasikan diri saat berada di kafe atau di taman. Ambil kopi yang dipesan, lalu lihat dan amati orang yang duduk dan lalu lalang. Perhatikan bahasa tubuh, mood, percakapan dan perilakunya. Diamati secara umum atau secara lebih spesifik.

c. Memainkan puzzle akan sangat membantu dalam memecahkan masalah. Dengan memainkan puzzle, akan banyak memperhatikan detail dan melihat dari sudut pandang berbeda. Menghabiskan waktu sendirian dalam memecahkan puzzle akan menajamkan pikiran dan memori. Selain itu, aktivitas memecahkan puzzle akan membuat menyadari akan keindahan suatu detail tertentu

d. Menonton film asing tanpa subtitle

e. Buat jurnal catatan observasi. Catat setiap hal yang diamati seperti apa yang orang pakai, mood dosen, dan burung di jendela. Jika berada di kafe, catatlah apa yang orang baca, makan atau diskusikan

Dalam hasil penelitian terlihat bahwa

Berdasarkan penelitian kemampuan observasi siswa pada tes-awal terlihat sangat baik. Beberapa siswa mampu mencapai nilai 80,00 dan 100,00 meskipun ada juga yang mendapat nilai 00,00 (tidak mengerjakan). Akan tetapi jika dilihat dari aspek aspek yang terdapat dalam indikator yang dijabarkan, pada tes-awal umumnya siswa menjabarkan hanya pada tiga aspek Indonesia sebagai negara berkembang yaitu aspek ekonomi, transportasi dan fisik. Siswa masih kurang dalam menemukan ciri atau dampak Indonesia sebagai negara berkembang dalam bidang sosial dan budaya.

Setelah melakukan treatmen dengan memperkenalkan kondisi Indonesia sebagai negara berkembang melalui kegiatan pembelajaran, observasi menggunakan media yang sangat interaktif melalui audio visual dan interaksi siswa lebih ditingkatkan maka keterampilan observasi siswa mengalami peningkatan.

Siswa mampu mendapatkan nilai maksimal 100 dan nilai terendah berada di angka 6 orang jika pada tes-awal adalah 0.

Hal lain terlihat dari keragaman indikator yang dijabarkan yaitu meliputi lima aspek ekonomi, sosial, budaya, transportasi dan fisik yang semula umumnya hanya tiga aspek. Pada aspek keterampilan observasi, Nilai rata-rata 68,13 dengan standar deviasi sebesar 29,56 varians 873,79 dan jangkauan adalah 100,00.

Nilai terendah pada tes-awal keterampilan observasi adalah 0,00 (nol) yang diperoleh 1 siswa atau sekitar 3,12\% dari total jumlah siswa. Nilai tertinggi adalah 100,00 yang diperoleh 10 siswa atau sekitar $31,25 \%$. Berikut sebaran jawaban siswa pada keterampilan observasi tes-awal berdasarkan indikator:

Kemampuan observasi siswa tentang ciri-ciri Indonesia sebagai negara berkembang umumnya siswa menjawab dengan menggunakan aspek ekonomi dan kondisi alam.

Sebanyak 32 siswa atau sekitar 96,87 siswa mampu memberikan gambaran ciri Indonesia sebagai negara berkembang. Hanya sedikit siswa yang memberikan gambaran indonesia sebagai negara berkembang dari aspek sosial yaitu sebanyak 2 siswa atau sekitar $6,25 \%$.

Siswa yang melakukan observasi dapat di lihat dari beberapa aktifitas di bawah ini:

1. Menggunakan berbagai perasaan untuk mengenali suatu objek.

2. Mencatat dengan detail fakta yang relevan dari objek dan segala sesuatu di sekitarnya.

3. Mengidentifikasikan persamaan dan perbedaan.

4. Menggunakan alat dan bahan untuk memahami objek dengan detail.

Adapun penjelasan dari indikator kemampuan observasi yang diambil dari penelitian ini adalah : 
1. Kemampuan menggunakan indera, Pengamatan pertama yang biasa dilakukan adalah dengan menggunakan panca indera manusia. Mata untuk melihat, telinga untuk mendengar, hidung untuk membaui, kulit untuk merasa dan lidah untuk mengecap. Pada kondisi tertentu, panca indera manusia dengan segala keterbatasannya tidak dapat mengamati atau mengobservasi lebih jauh. Pada kondisi ini diperlukan adanya alat bantu yang peka terhadap perubahan yang sesuai dengan pengamatan yang dilakukan.

2. Kemampuan mencari fakta-fakta yang relevan. Observasi merupakan proses seleksi, demi tercapainya tujuan dari suatu pengamatan. Pengumpulan fakta-fakta yang relevan dipengaruhi oleh harapan, pengalaman dan pengetahuan pengamat mengenai apa yang sedang diamatinya. Fakta-fakta yang diperoleh berasal dari hasil tulisan, gambar dan pola tertentu sebagai hasil penjabaran dari observasi. Harapan yang ada dalam pikiran pengamat akan mempengaruhi pengamatan yang dilakukan. Untuk menghindari hal tersebut pengamat hendaknya dalam netral atau perlu adanya kejujuran dengan apa yang dilihatnya. Selain itu, pengamat perlu menguasai terlebih dahulu kerangka konseptual mengenai apa yang sedang diamatinya. Dengan demikian, pengamat akan mampu membaca fakta-fakta dari hasil pengamatan.

3. Kemampuan dalam mencari persamaan dan perbedaan. Setelah pengamat mengumpulkan data yang tepat mengenai hal yang diamati, langkah selanjutnya pengamat perlu menelaah data hasil pengamatan. Kecenderungan dari hasil pengamatan perlu diketahui agar dapat dengan mudah mengambil kesimpulan dari hasil pengamatan. Kemampuan dalam mencari persamaan dan perbedaan dari objek atau peristiwa yang diamati dapat memandu pengamat untuk menemukan hubungan diantara fakta-fakta yang telah diamatinya. Dalam mencari persamaan dan perbedaan dari suatu objek atau peristiwa akan melibatkan keterampilan membandingkan sesuatu. Hal ini akan turut memberikan kesempatan kepada siswa sebagai pengamat untuk mengembangkan kemampuan observasi. Kemampuan mengidentifikasikan perbedaan diantara objek atau peristiwa yang sama dan mampu mengidentifikasikan persamaan diantara objek atau peristiwa yang berbeda dengan yang lainnya merupakan salah satu kemampuan yang penting dalam penyelidikan.

Guru dapat membantu siswa mengembangkan kemampuan dalam mengobservasi dengan cara memberikan kesempatan kepada siswa menggunakan alat-alat indera untuk memperoleh fakta dari objek atau fenomena yang diselidiki. Selain itu sangatlah baik apabila guru menarik minat siswa dengan menggunakan objek yang dipersiapkan di meja untuk diamati dan secara esensi dari objek-objek yang ditampilkan atau mengajak siswa untuk melakukan percobaan-percobaan sederhana.

\section{SIMPULAN}

Kesimpulan dari penelitian ini pada dasarnya siswa yang bersekolah di Sekolah Dasar Negeri Rawamangun 12 telah mampu mengobservasi objek-objek sosial dalam materi IPS dengan menggunakan metode inkuiri terbimbing, siswa mengalami peningkatan yang signifikan. Oleh sebab itu dengan model-model yang mengutamakan aspek berpikir tinggat tinggi pada siswa, mengakibatkan siswa mengalami hasil belajar yang baik. 


\section{DAFTAR PUSTAKA}

Ahmar, Dwi Agung P (2012) Pelaksanaan Pembelajaran Ipa Berbasis Lingkungan Alam Sekitar Kelas lii Di Sd Islam Terpadu Ibnu Mas'ud Kulon Progo. S1 thesis, UNIVERSITAS NEGERI YOGYAKARTA.

Aqip, Z. 2006. Penelitian Tindakan Kelas, Jakarta, Yrama Widya. Arikunto, S. 2002. Prosedur Penelitian Pendekatan Suatu Praktek. Jakarta:

Rineka

Bektiarso,S. 1997. Pengembangan Konsep Siswa. Majalah IImiah Pancaran Pendidikan Th. X No 38. Jember: FKIP Unej.

1997, Pembelajaran IPA dengan Model Siklus Belajar di SD Negeri Antirogo 03 Jember, Tesis, IKIP Bandung, tidak diterbitkan.

Dahar, R.W. 1989. Teori-Teori Belajar. Jakarta: Erlangga.

Dimyati dan Mudjiono. 1999. Belajar dan Pembelajaran. Jakarta: Rineka Cipta.

Druxes, dkk. 1986. Kompedium Dikdaktik Fisika. Bandung: Remaja Karya.

Hamalik, O. 1993. Strategi Belajar Mengajar. Bandung: Mandar

Hasibuan dan Moedjiono. 1985. Prosedur Belajar Mengajar. Bandung: Remaja Karya.

Natsir, 1997, Pembelajaran IPA dengan Model Pembelajaran Novick, Tesis, IKIP Bandung, tidak diterbitkan.

Saptono, 1997, Pengembangan Konsepsi IPA Sekolah Dasar dengan Pembelajaran Aktif, Tesis, IKIP Bandung, tidak diterbitkan.

Slameto, 2004, Belajar dan faktor-faktor yang mempengaruhinya, Jakarta, Rineka Cipta.

Winahyu, 1997, Penggunaan Penilaian Kinerja dalam Pembelajaran IPA di Sekolah Dasar, Tesis, IKIP Bandung, tidak diterbitkan.

Wuryastuti, 1997, Pembelajaran IPA di sekolah dasar dengan Model Interaktif, Tesis, IKIP Bandung, tidak diterbitkan.

Rusyan, Kusdinar, \& Arifin, 1994, Pendekatan Dalam Proses Belajar Mengajar,Bandung, Remaja Rosdakarya. 